\title{
Olvasóink véleménye a hazai egészségfejlesztés színvonalának emeléséről
}

\author{
Readers' opinions on raising the level of the Hungarian \\ health promotion
}

doi: $10.24365 /$ ef.v58i4.220

Az Egészségfejlesztés folyóirat október végén kérdőívet küldött olvasóinak a hazai egészségfejlesztés színvonalának emeléséről. Az olvasóinknak feltett kérdések a szerkesztőség nagy örömére komoly érdeklődést váltottak ki: az online kérdőívet a válaszadásra rendelkezésre álló három hét alatt mintegy 800-an nézték meg, és közülük 150-en szántak időt a kitöltésére. A válaszok tartalmi elemzése alapján sejthető, hogy a témáról nemcsak a lapot olvasó népegészségügyi szakértők, hanem más területeket - például az orvoslást, vagy a pedagógiát - képviselő szakemberek is véleményt formáltak.

Az alábbiakban a válaszokat röviden összegezzük, és - amint azt ígértük -, az eredmények ismertetését követően egy műhelybeszélgetésen lehetőséget adunk az olvasói vélemények közös értékelésére a jövő év elején.

1. Sorolja fel az utóbbi évek 3 LEGSIKERESEBB országos jelentőségű népegészségügyi intézkedését! $A$ népegészségügyi intézkedések, tevékenység alatt értve jogszabályok alkotását, programok vagy projektek indítását, szervezeti változtatásokat.

A szabadszavas válaszokat először kategorizáltuk, majd nagyobb csoportokba összevontuk (egyes kategóriák több csoportba is kerülhettek). Az alábbi kördiagram bemutatja, olvasóink mely népegészségügyi intézkedéseket, tevékenységeket tartották a legsikeresebbeknek.

A válaszadók ötöde legsikeresebbnek a népegészségügyi célokat szolgáló jogszabályokat (népegészségügyi termékadót, a nemdohányzókat védő és a köznevelési törvényt, a közétkeztetési, valamint az élelmiszerek transzzsírsavtartalmának korlátozá- sára vonatkozó rendeletet) tartotta. A jogszabályalkotás mellett az olvasók 31\%-a az egészséges magatartást, azaz az egészséges táplálkozást, a több testmozgást és a dohányzás visszaszorítását előmozdító intézkedéseket ítélte sikeresnek. Ilyenek voltak például az iskolagyümölcs-program, a mindennapi testnevelés vagy a dohányárukra vonatkozó áremelés.

Bár a kérdés a népegészségügyi intézkedésekre vonatkozott, a válaszolók tizede sikeres, az alap-, illetve szakellátás színvonalát emelő intézkedéseket (pl. e-recept vagy a kórházak felújítása) is említett.

\section{Sorolja fel az utóbbi évek 3 LEGKEVÉSBÉ SIKERES} országos jelentőségű népegészségügyi intézkedését! A népegészségügyi intézkedések, tevékenység alatt értve jogszabályok alkotását, programok vagy projektek indítását, szervezeti változtatásokat.

A legkevésbé sikeres intézkedések kategorizálásakor megpróbáltunk a sikeresekéhez hasonló csoportokat képezni, de a népegészségügyi intézményrendszer átszervezésével a válaszadók mintegy ötöde nem értett egyet, és emiatt egy újabb csoportot kellett létrehozni. Helytelennek tartották többek között az országos háttérintézetek összevonását és az ÁNTSZ helyi szervezeteinek a közigazgatási hivatalokba történő átszervezését.

A felmérésben részt vevők negyede sikertelennek tartotta a viselkedésváltoztatásra (táplálkozás, mozgás, dohányzás) irányuló népegészségügyi intézkedéseket, ami azért is meglepő, mert közel harmaduk pedig éppen sikeresnek ítélte. Hasonlóan megosztottak a vélemények a többi kategóriában is: a válaszoló olvasók negyede sikertelennek, tizede sikeresnek véli az orvosi ellátás fejlesztését. 
A válaszadók véleménye szerint a szürés esetében 13\%-ban sikertelen volt, 12\%-ban sikerrel járt a fejlesztés. Az egészségfejlesztésre (mint pl. az
Egészségfejlesztési Irodák, az EFI-k felállítása) vonatkozóan 13\% negatív, 7\% pozitív megítélést tapasztaltunk.
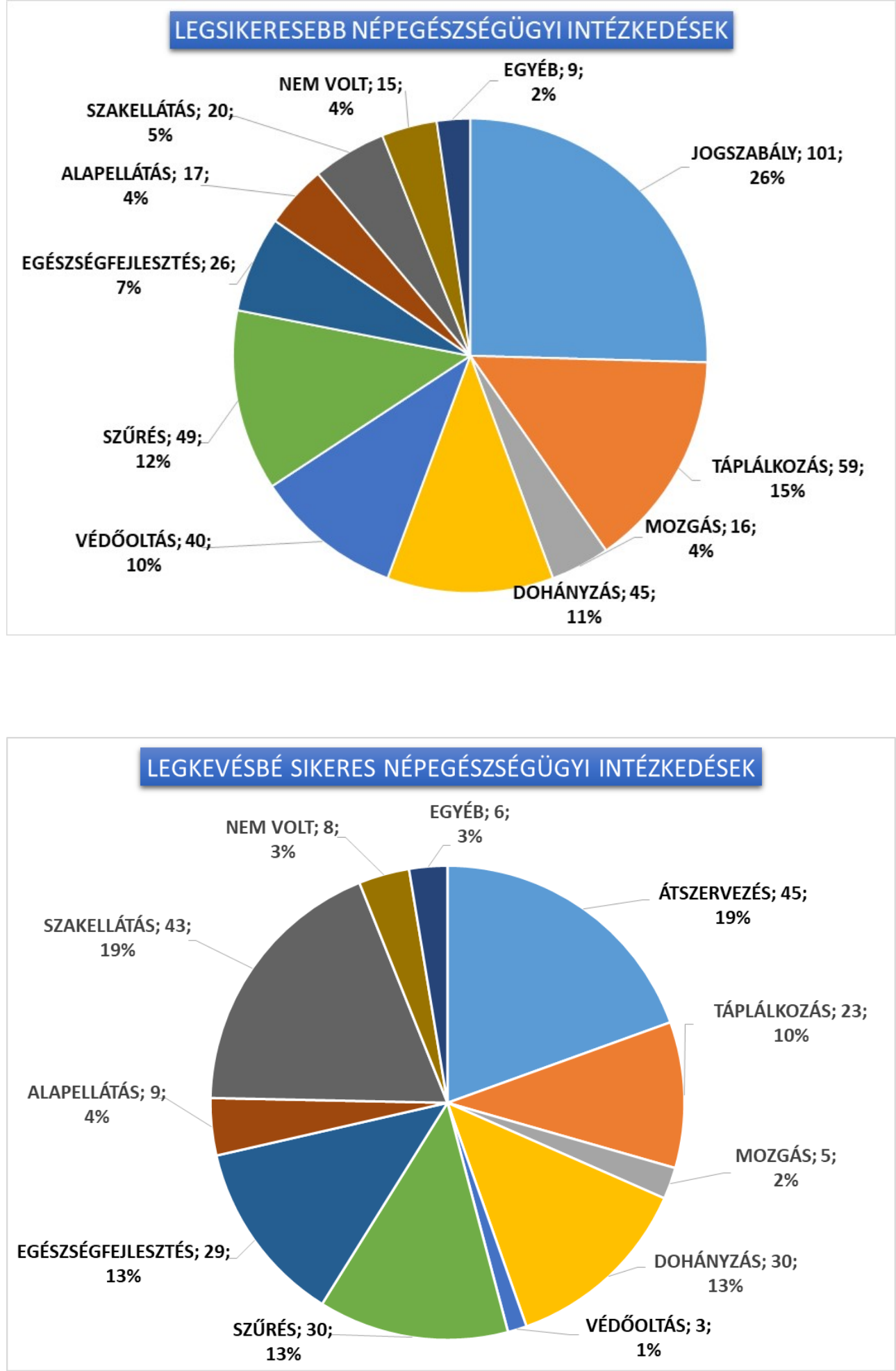
3. Milyen osztályzattal értékelné a hazai népegészségügy SZERVEZETI feltételeit? Szervezeti feltételek alatt értve, hogy a jelenlegi népegészségügyi tevékenységet végző intézményi rendszer mennyire tud hozzájárulni a lakosság egészségének javitásához.

A válaszok átlaga az 1-től 5-ig terjedő skálán osztályozva: 2,4 volt.

4. Milyen osztályzattal értékelné a hazai népegészségügy ANYAGI feltételeit? Anyagi feltételek alatt értve a népegészségügyi tevékenységek végzéséhez rendelkezésre álló pénzt, eszközöket, segédanyagokat.

A válaszok átlaga: 2,1 volt.

5. Milyen osztályzattal értékelné a hazai népegészségügy SZEMÉLYI feltételeit? Személyi feltételek alatt értve a népegészségügyi szakemberek számát és felkészültségét.

A válaszok átlaga: 2,6 volt.

6. Milyen osztályzattal értékelné a hazai népegészségügy EREDMÉNYESSÉGÉT? Eredményesség alatt értve, hogy a hazai népegészségügy összességében mennyire tud hozzájárulni a lakosság egészségének javitásához.

A válaszok átlaga: 2,5 volt.

7. Ha Önön múlna, milyen szakpolitikai intézkedéseket kezdeményezne a népegészségügyi rendszer megerősítésére, hogy a lakosság egészségmutatói megközelítsék az uniós átlagot? Szakpolitikai intézkedés lehet pl. szervezeti átalakitás, erőforrások bóvitése vagy átstrukturálása, feladatellátás elöirása, és egyéb jogszabályok alkotása. A szakpolitika számára javasolt intézkedéseket nem szükséges fontosság szerint sorba rendezni.

A válaszolók javaslatainak feldolgozásakor némileg el kellett térni az előzőkben alkalmazott kategóriáktól és csoportoktól. Elsőként említendő a népegészségügyi stratégia, program kidolgozására és megvalósítására vonatkozó javaslatok. E nélkül - vélik sokan - nem lehet összehangolni, hatékonnyá tenni a népegészségügyben megvalósítandó fejlesztése- ket. A szektoron belüli, illetve az interszektoriális együttmúködések (pl. az élelmiszeriparral) nélkülözhetetlenek a sikerhez, az egészség javításához, az igazságtalan különbségek kiegyenlítéséhez.

A javaslatok legnagyobb arányban a humán erőforrás fejlesztését említették. A vélemények szerint több és jobban képzett szakemberre, pályán maradásra ösztönző bérekre, vonzó munkahelyi környezetre és megfelelő szakmai kihívásokra lenne szükség.

Az emberi erőforrások mellett anyagira is nagy szüksége lenne - véli a válaszolók jó része. Itt nemcsak több népegészségügyben elköltött forintra gondolnak, hanem ideértik a jobb infrastruktúrát, a korszerübb eszközöket is.

A javaslatok következő nagyobb csoportja a népegészségügy intézményrendszerének fejlesztésére vonatkozik. Ezek magukba foglalják az önálló egészségügyi minisztérium és országos intézmények létrehozását, a szervezetek közötti feladatmegosztás újragondolását, az EFI-k és a védőnői szolgálat fejlesztését vagy a hazai egészségmonitorozás rendszerének kialakítását is.

Hasonló gyakorisággal tesznek javaslatot a megelőzés kiemelt fejlesztésére. Itt az elsődleges és másodlagos szürések kiterjesztése, a részvételi hajlandóság jutalmazással vagy büntetéssel való növelése mellett a családcentrikus programok is említésre kerülnek. Ide sorolhatók, de külön említendők az óvodai és iskolai egészségfejlesztésre (nevelésre) vonatkozó javaslatok is. Az előzőktől ugyancsak nem elválasztható, de a javaslatok között gyakran jelenik meg az egészségkommunikáció fejlesztése, az egészséges életmód lakosság körében történő népszerúsítése.

A szakemberek körében mindinkább elfogadottá válik, hogy az egészség javításához nem elég az egyéneket rávenni, hogy éljenek egészségesebben, ehhez nélkülözhetetlen az egészséget támogató környezet is. Erre vonatkozó javaslatokat többen is megfogalmaztak: növelni szükséges a testmozgásra, sportolásra alkalmas intézményekhez vagy szabadtéri pályákhoz való hozzáférést, továbbá korlátozni kellene az egészségkockázatot jelentő, illetve növelni kellene a magas tápértékű élelmiszerekhez való hozzáférést. A további javaslatok között szerepel például a közétkeztetés színvonalának emelése, ezzel összefüggésben a helyi mezőgazdasági termelők támogatása is. 
A lakosság egészségének javításához a kérdőívet kitöltő olvasóink több mint tizede - a népegészségügyi intézkedéseken túl - az alapellátás, illetve a szakellátás fejlesztésére vonatkozóan is fogalmazott meg javaslatokat. Ezek között a háziorvosok továbbképzése és az informatikai fejlesztés mellett az elhízott gyermekeket ellátó központ is szerepelt.

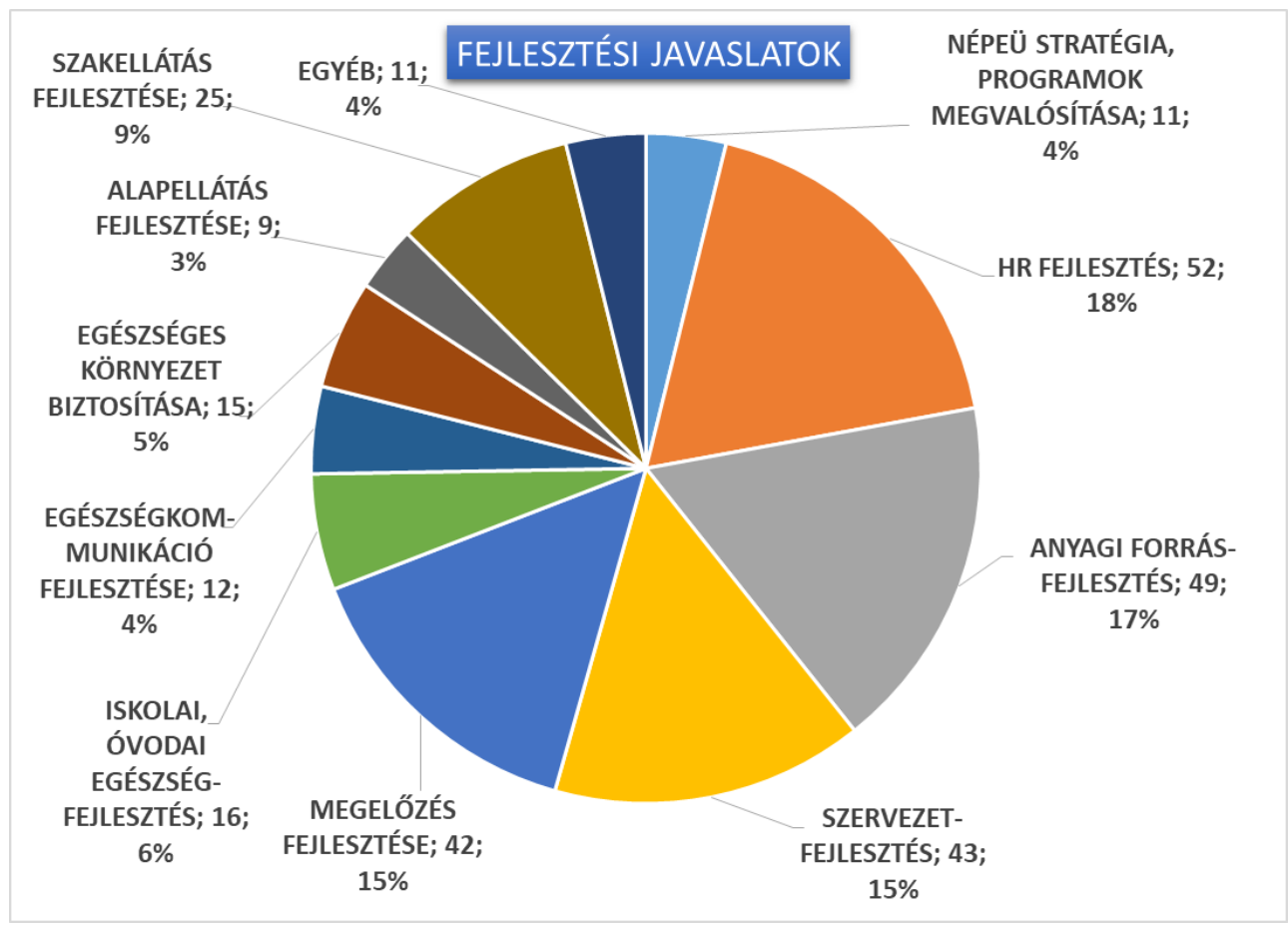

\section{Összegzés}

Bizakodásra okot adó az a tény, hogy az Egészségfejlesztés folyóirat olvasói közül sokan vállaltak önként feladatot azzal, hogy véleményt formáltak a népegészségügy, ezen belül az egészségfejlesztés előmozdításáért. A magas részvétel egyértelmúvé teszi, hogy a szakemberek szükségét érzik és készek is tenni a népegészségügyért.

A hazai népegészségügy legfontosabb területei a válaszok alapján egyértelműen kirajzolódnak. Ezek közül jelentőségével kiemelkedik az elsődleges megelőzés, az egészséges életmód előmozdítása és az azt támogató környezet kialakítása. Az erre irányuló jogszabályokkal, intézkedésekkel voltak leginkább elégedettek a válaszolók. Azonban ugyancsak e területen várnának több és hatékonyabb beavatkozást, hiszen a lakosság egészségmutatói további intézkedések szükségét jelzik. (Lásd a „Hazai egészség-pillanatkép” című írást ebben a lapszámban.)
A válaszokból kiolvasható az olvasók meggyőződése, hogy ehhez a szektoron belüli és az interszektoriális együttműködés, az összehangolt cselekvés nélkülözhetetlen. Ennek feltételeként a választ adó olvasók a népegészségügyi intézményrendszer, a szakmai irányítás, feladatmegosztás megújítását látják. A népegészségügy megerősítésének további feltétele a vélemények alapján, a szakterület jelenleg igen szúkösnek tartott erőforrásainak bővítése. Az erőforrások észszerű elosztását, hatékony felhasználását a nemzetközi tapasztalatok és a hazai helyzetelemzés alapján elkészített átfogó népegészségügyi stratégia, program biztosíthatja, aminek megvalósítása eredményeképpen a magyar lakosság egészségmutatói megközelíthetik az uniós átlagot.

Köszönjük aktív részvételüket kérdőíves felmérésünkben, és az egészségfejlesztés színvonalának emelése érdekében a közös gondolkodást egy múhelybeszélgetés alkalmával folytatjuk. 